\title{
On Understanding and Required Actions in Tasks of Written Examinations
}

\author{
Marcel Köhler \\ University of Applied Sciences Dresden (FHD) Güntzstraße 1, 01069 Dresden, Germany
}

\begin{abstract}
The study deals with the conscious use of the medium "language" in the design of vocational teaching/learning processes in order to make the examination and assessment process of learning outcomes more transparent and appropriate. For this purpose, the study focuses on the use of tasks in written examinations in vocational teaching and in particular on the operators used in these. The question will be investigated as to whether the teaching of operator meanings and the actions required with them leads to an improvement in the results of processing and the understanding of tasks among learners. The theoretical approach is based on the knowledge and action theory of AEBLI (1980; 1981), on the basis of which an instrument is developed for verifying the understanding of tasks. To answer the question, a quasi-experimental intervention study in pretest posttest design with one experimental and control group $(n=42)$ is carried out. For this purpose, the instrument is used to verify the understanding of the tasks in the vocation "educator" at a vocational school. For the development of the treatment, selected operators are conceptually defined, which are frequently used in written final examinations of this profession. The experimental results show that instruction on operators has a significant positive effect on the results of the tasks performed by the learners in the experimental group. This is also obvious for an improved understanding of the learner's tasks, since here too there are significant positive changes in individual segments of understanding. Finally, conclusions are derived for the development of a mutual understanding of the tasks of teachers and learners as well as for the pedagogical-practical activity of vocational teaching.
\end{abstract}

Keywords: operator, academic-pedagogical special language, speech comprehension, didactic order

\section{Introduction}

Teaching and learning in class have always been significantly linked to natural language, communication and interaction and are therefore unthinkable without the use of linguistic means. Priesemann (1971) and Montag (1975) refer to the specificity of this teacher's language in class by showing that the teaching process is predominantly based on communication bound to language and that verbal language in class has a didactic intention and objective. Spanhel (1973) describes the relationship between language and teaching and places the language of instruction as the "domain language" of organised school work at the center of his investigations. In this way he distinguishes the language of instruction from everyday language and approaches it as an independent specialised language. This development becomes even clearer in the work of Lüders (2004). Following his argumentation, the social relationship between teacher and learner can be conceived primarily as an interactional relationship with special consideration of language. In this interaction relationship, teacher and learner are to be understood as acting persons. Acting has the goal of developing the personality of the learners. For this purpose the use of language by teachers plays a key role in teaching (cf. Loch, 1970, p. 481 et sq.; Kostrzewa, 2009, p. 29). Among other things, language is used by teachers in class to initiate and regulate learning processes and to receive feedback on what students have learned. Understanding the words used by the teacher is thus of fundamental importance for the acquisition of knowledge in class. Language can thus be regarded as a central element of teaching that contributes to meeting social requirements. This applies to oral language as well as to written language. This basic assumption also has an effect on didactic considerations regarding the designing and understanding of didactic orders in written learning success assessments. Special attention should be paid to the operators or action-prompting verbs used in tasks (cf. Author, 2017, p. 328 et sq.). 
In contrast, the research and data situation on the language of instruction in general, and on instructional communication and language comprehension in vocational education in particular, must be described as extremely precarious. In Germany, the need for research on the subject of the "language of instruction" is particularly evident in the lack of (regulatory) tools in many areas of vocational education. Such tools could be used to design didactic orders, for example, in written examinations in vocational training and education and in final examinations of vocational training courses. It is therefore necessary to conduct studies that can be used to make scientifically founded statements on the language used in vocational class or its linguistic design. These studies will be used to systematise existing research findings and can serve as a basis for systematisation. On this basis, research possibilities open up that lead to well-founded statements about linguistic idiosyncrasies in vocational education and training. The resulting consequences can contribute to a targeted and requirementoriented design of linguistic processes in teaching.

\section{Current state of research and research question}

Various scientific disciplines focuses on the phenomena of language, communication and interaction. In the 20th century, the names of well-known representatives of the humanities and social sciences from philosophy such as Popper (1934), Rorty (1967), Searle (1971) or Habermas (1981) and sociology such as Parsons (1937) or Luhmann (1984), among others, are associated with the fundamental shaping of lines of research and scientific development on language, communication and interaction. Works by researchers of linguistics such as Chomsky (1957) or Lakoff (1987), psycholinguistics such as Leont'ev (1971) or Lurija (1982), developmental psychology as well as pedagogically oriented psychology such as Piaget (1969), Wygotski (1977) or Aebli $(1980 ; 1981)$ can also be assigned to these lines of research and have influenced their development.

The beginning of modern teaching language research in this period can be traced back to the $60 \mathrm{~s}$ of the 20 th century (cf. Fromme, 1997, p. 83 et sq.; Lüders, 2003, p. 119). Under the influence of the linguistic turn, language became a central object of social science research during this period, which led to cooperation between different scientific disciplines such as psychology, anthropology, ethnology and sociology with the aim of bringing together linguistic and subject-specific research approaches (cf. Kostrzewa, 2009, p. 29). The connection between language and cognitive processes also gained enormous importance, as is made clear by the research of Piaget (1969), Aebli (1980; 1981), Wygotski (1977) or Anderson (1989) and other renowned authors. On the other hand, over the years the branch of research called linguistic criticism has developed, which is concerned with the evaluation of language in specialist disciplines such as philosophy or sociology, but also in social conditions.

Even though a research tradition based on sociolinguistic and ethnomethodological approaches developed in the 1970s and 1980s, research on the language of instruction is still considered to be rather underrepresented today (cf. Lüders, 2004, p. 700). Under the influence of the developments of the past five decades, the scientific view of the teaching process has changed. On the one hand, linguistic research has found indications that participation in class requires certain linguistic skills and the use of specific forms of communication on the other (cf. Lüders, 2003, p. 120; Kostrzewa, 2009, p. 30 et sq.). In addition to this, the epistemological interest in research on instructional language moved to the centre of sociological studies, since a connection between linguistic abilities and their development with the course of educational careers was postulated (cf. Lüders, 2003, p. 119). In addition to the conceptual-systematic scientific treatment, the language of instruction became the subject of empirical research in pedagogy and didactics in the second half of the 20th century, resulting in a broad spectrum of empirical findings on the language of instruction. An overview of central studies in the development of research on the language of instruction can be found, for example, in Lüders (2003, p. 119 et sq.).

The aim of this study is to gain insights into the understanding of didactic orders in vocational theory lessons. Since these are applied in all teaching sections (cf. Hortsch, 2005, p. 39), for pragmatic research reasons a 
restriction must be made for the implementation of the study. In the following, therefore, only the tasks of the teaching section "Control and Assessment" (cf. ibid.) will be subjected to a more concrete examination. The focus will be placed particularly on the form of examination used in this section of the course, the written assessment of learning success and the written tasks, whereby the verbs/operators used in the tasks of this form of examination are of particular interest for the present study. Based on the problems described and the current state of research, the following question is addressed in this study:

Q1: $\quad$ Does the teaching of operators in lessons lead to a mutual understanding of tasks among teachers and learners?

\section{Understanding of tasks in written examinations}

While language is the subject of several scientific disciplines, studies on the process of understanding, the construction of knowledge structures and similar processes or phenomena can be assigned in particular to cognitive psychology (cf. Pastohr, 2008, p. 58). The explanatory framework for the selection of a cognitive psychological theory of understanding written tasks can be found in the text production models developed since the 1980s. Exemplary reference is made here to the work of Bereiter and Scardamalia $(1986 ; 1987)$ and Hayes (1996). These models have in common that the writing process is linked to cognitive processes as well as to mental knowledge representation by means of schemata. An understanding theory suitable for this investigation, which relates cognitive processes to action and understanding, is provided by Aebli (1980; 1981).

Aebli describes in his theory, among other things, the connection between action and knowledge, which is significant for this investigation. Action is defined here as intentional as well as highly conscious and goaldirected behaviour (cf. Aebli, 1980, p. 19 et sq.). Action precedes thinking and is structurally similar to it, since both action and thinking put elements (e.g. participants or components of action) to each other (cf. ibid., p. 13). This applies to both practical action and linguistic action. Since knowledge is in turn necessary for cognitive processes, the relationship between action and knowledge has an interdependent character according to the definition introduced here. Knowledge is thus not only a source of new action, but is also generated by the action of a subject in his or her environment (cf. Sonntag, 1993, p. 38). Knowledge is generated in a constructive process of development, in which individual elements and the relations between them are structurally linked (cf. Aebli, 1981, p. 270). The result is a unique knowledge structure that can only be found in the individual (Hortsch, 2005, p. 64). In the course of the constructive development process it is possible to create new knowledge structures and to submit existing knowledge structures to changes and thus modify them (cf. Sonntag, 1993, p. 39). A knowledge structure is thus an order of the contents of long-term memory that is created by action (cf. ibid., p. 38). A knowledge structure can be illustrated as a net-like structure consisting of nodes or objects connected by relations (cf. Aebli, 1980, p. 158). The set of these objects includes both participants in actions and elements in operations and terms in relations (cf. Aebli, 1981, p. 270). With knowledge structures, a differentiation into knowledge systems and schemata can be made (cf. ibid.).

Knowledge systems are characterised by the fact that their elements are neither directed towards a goal nor are they earmarked for a specific purpose, but are rather present on a single level or a ahierarchical arrangement (cf. Aebli, 1980, p. 158). They can be acquired in two ways. On the one hand, they arise through levelling or transformation from schemata and on the other hand through the purposeless linking of elements in the perception of reality (e.g. through purposeless observations) (cf. Aebli, 1981, pp. 195-205). Knowledge systems unite in themselves both the processual core of actions and the relational core of concepts and operations and are thus the starting point for the reconstruction or hierarchical arrangement of their elements into schemata (cf. ibid., p. 270.).

The formation of schemata, in turn, is achieved by linking elements to form a hierarchically structured goalrelated and purpose-related construct (cf. Aebli, 1980, pp. 83-86). However, the structure of schemata does not correspond to a rigid structure. Rather, schemata can be filled with new information, reorganised or restructured, 
or over time further differentiated or generalised for better applicability (cf. Mandl et al., 1988, pp. 126-130; Schnotz, 1994, pp. 86-90). Thus schemata can be understood as dynamic, complex and interrelated constructs (cf. Pastohr, 2008, p. 67). Pastohr (ibid.) points out that with the help of schemata it is possible to direct attention to certain information and to understand, interpret and process it, for example by working on tasks or solving problems. The acquisition of new knowledge takes place by activating and situation-specific configuration of existing schemata through active engagement with the environment (cf. Schnotz, 1994, p. 87). For this purpose, existing systematic knowledge is used to reproduce or reconstruct schemata that appear most suitable for action in the respective prevailing situation. In his theory, Aebli differentiates between a schema of action, schema of operation and schema of conception.

\section{Schema of action}

The availability of schemata of action corresponds with the available action knowledge of an individual. In this type of schema, the knowledge elements are oriented towards an action goal, which forms the top of the schema or the hierarchically arranged knowledge elements (cf. Aebli, 1981, p. 197). Schemata of action are regarded as building blocks of action based on organised knowledge, from which they are generated and which ensures their implementation (cf. Aebli, 1980, p. 83 et sq.). Schemata of action are characterised by the fact that they are repeatable, that they can be transferred to new tasks and situations and that they have the invariant structure of an action necessary for repeatable execution (cf. ibid., p. 84).

\section{Schema of operation}

On the basis of practical action, operations can be formed by retrospective abstract consideration of the action (cf. Aebli, 1990, p. 204). While the establishment of relationships between individual elements in a practical action takes place concretely, this happens abstractly in an operation, i.e. independently of a concrete action situation (cf. Aebli, 1980, p. 214). Therefore not only the action but also the result of the operation is seen abstractly.

\section{Schema of conception}

In the conceptual schemata, the net-like systematic knowledge is directed towards a point or a node of the net, which encompasses the term to be formed and, as a word, forms the apex of the schema (cf. Aebli, 1981, p. 111). From each node of the network a term can be set up hierarchically (cf. ibid., p. 108 et sq.). This allows for different views of the available knowledge material, which Aebli (1981) describes as the possibility of taking different perspectives. This term is used to illustrate that the nodes and relations lying under the tip of the raised net are literally illuminated. Put differently, they become visible when taking a certain perspective, and the meaning of the term thus becomes accessible to the individual (cf. ibid., p. 111).

The individual types of schemata should not be considered in isolation from each other. They are connected with each other. This means that individuals ultimately transform schemata of action into operational schemata in a transformation process by internalising, abstracting and systematising practical action (cf. Pastohr, 2008, p. 64). They also develop conceptual schemata through the linguistic objectification of things, characteristics, relations, actions and operations (cf. ibid.). The fundamental difference between the individual types of schemata is the purpose for which the hierarchical arrangement of the elements of systematic knowledge takes place (cf. ibid., p. 66).

Understanding therefore necessarily goes hand in hand with the acquisition of schemata. In conformity with theory, understanding can thus be defined as a coherent mental representation that is adequate to the object or task to be understood (cf. Schnotz, 1994, p. 32). A mutual understanding of a task by teacher and learner can therefore be established when the knowledge structures of the learners are set up by the operator of a task. By 
such a purpose-related hierarchisation of the learners' knowledge the integration of the task into the existing knowledge of a learner can be verified. Due to the focus on teaching about the meaning and the handling of an operator in class, such a mutual understanding is assumed between teachers and learners. In order to answer the question, and taking into account the state of research and theoretical considerations, the following hypothesis is formulated for further investigation:

H1: $\quad$ Teaching about the meaning and the handling of operators of written tasks lead to a hierarchical structure of the knowledge structures of the learners with regard to the action required by the teacher in the task.

\section{Study design, survey instruments and research methodology}

To answer the scientific question, a quasi-experimental intervention study in pre-test-post-test design with one control $\left(G_{C}\right)$ and one test group $\left(G_{T}\right)(n=42)$ each will be conducted (cf. Author, 2017). The experiment involves 2 school classes of the training occupation "state-approved educator". In order to increase internal and external validity by controlling important situation- and time-related confounding variables, both classes will be parallelised (cf. Klauer, 2005, p. 79). This parallelisation takes place at the level of the organisation of training and at the level of teaching. For parallelisation the students of both involved classes are in the same vocational training course in the first year of training at the same school. Beyond that the intervention is carried out by the same teacher in both classes and the experiment is carried out simultaneously in both classes. In addition the intervals between the two survey dates are identical for both classes.

In contrast to the control group, an intervention takes place in the test group between pretest and posttest, in which the handling of operators is discussed and practiced during the lessons. The intervention is carried out by a teacher who has been known to the students since the beginning of their education and who has a high level of expertise in the design of examination tasks. In preparation, the teacher receives instructions on the contents of the test and on the planned procedure. For the development of the treatment, it is necessary to refer to Aebli's theory $(1980 ; 1981)$ and to include scientific literature on descriptions of actions to be performed, on which the operators in tasks ask for, and on the meanings of the individual operators.

Research on this topic has been successful in encyclopaedias on philosophy and epistemology (cf. Blackburn, 1996; Halder, 2003; Mittelstraß, 2004), the German language (cf. Pfeifer, 1989) and especially in the linguistic specialist literature. Didactically relevant findings on some operators can be referred to in relevant publications from the research area of functional-communicative language description, which appeared mainly in the 1970s and 1980s (cf., for example, Conrad and Zenker, 1977; Schmidt, 1981). The inclusion of this research work in the present study makes sense, since the communicative procedures examined in those studies are understood as types of linguistic-communicative action (cf. Harnisch, 1983, p. 41) and consequently correspond with the underlying understanding of the operator as a verb that calls for a specific action in the tasks of written examinations. For this study, the operator "analyse" is explicated. In addition, a proposal is made for the implementation of the required action in written examinations. The operator "analyse" is often used in training to become a "state-approved educator" (cf. Author, 2017, p. 181). For this reason, the action required with this operator is regarded as significant for work in this profession. The following definition of the operator is taken as a basis for the investigation:

"The operator "analyse" is understood as the request to carry out a systematic investigation of a given object of appropriation, in which an object is broken down into its elements, properties and relations according to criteria, these are examined in an orderly manner and evaluated free of subjective values. The results of the investigation process can be used as a basis for drawing conclusions for further actions on this object of appropriation." (Author, 2017, p. 194) 
Since an analysis qua definition is understood as a systematic procedure, the following sub-steps are proposed for the realisation of an analysis process in written examinations of the vocational training course "stateapproved educator" (see Table 1). The description of the sequence of steps assumes that the analysis is to be conducted on the basis of a learning situation given in text form (see Author, 2017, p. 196):

Table 1: Suggested action steps for implementing the operator " analyse".

\begin{tabular}{ll} 
Step & \multicolumn{1}{c}{ Description } \\
\hline 1 & Reading of the didactic order and the text in accordance with the didactic order \\
\cline { 2 - 2 } 3 & Writing down of a short summary \\
4 & Writing down of the analysis criteria \\
5 & $\begin{array}{l}\text { Structuring of and writing down the content of the learning situation to be worked on } \\
6\end{array}$ \\
7 & Examining and writing down the characteristics of the individual components of the learning \\
\cline { 2 - 2 } & Drawing conclusions from the analysis \\
& Writing down an analysis result
\end{tabular}

Since a direct evaluation of the understanding of the task in this quasi-experiment is not possible, an operationalisation for the formation of concluding indicators is carried out on the basis of Aebli's theory (1980; 1981). The operationalisation is carried out via several index levels. A distinction is made between the course of action and the result of applying the operator-specific mental representation to the task to be worked on, on the basis of which a mutual understanding of the task by teacher and learner can be tested. According to Aebli's theory, a distinction is made between the 3 described schema types. The indicators formed are then subdivided into the individual action steps of the operator "analyse" used in the tasks (see Table 2). 
Table 2: Operationalisation with indices and indicators.

\begin{tabular}{|c|c|c|}
\hline \multirow[t]{3}{*}{$\begin{array}{l}\text { Iva1.1: } \\
\text { Course of action of } \\
\text { applying an operator- } \\
\text { specific consistent, } \\
\text { coherent mental } \\
\text { representation to a } \\
\text { task }\end{array}$} & $\begin{array}{l}\text { Iva1.1.1: } \\
\text { Course of action of the } \\
\text { application of an operator- } \\
\text { specific schema of } \\
\text { conception during the } \\
\text { processing of a task }\end{array}$ & $\begin{array}{l}\text { IVA1.1.1.1: During the processing of the task, the } \\
\text { perspective taken on the operator } \\
\text { according to the taught learning content is } \\
\text { depicted. }\end{array}$ \\
\hline & $\begin{array}{l}\text { Iva1.1.2: } \\
\text { Course of action of the } \\
\text { application of an operator- } \\
\text { specific schema of } \\
\text { operation during the } \\
\text { processing of a task }\end{array}$ & $\begin{array}{l}\text { IVA1.1.2.1: In the structure of the answer the } \\
\text { development of the structure of the taught } \\
\text { operator-specific action is recognisable. } \\
\text { IVA1.1.2.2: The taught individual steps of the operator- } \\
\text { specific action are correctly linked to each } \\
\text { other. }\end{array}$ \\
\hline & $\begin{array}{l}\text { Iva1.1.3: } \\
\text { Course of action of the } \\
\text { application of an operator- } \\
\text { specific schema of action } \\
\text { during the processing of a } \\
\text { task }\end{array}$ & $\begin{array}{l}\text { IVA1.1.3.1: The individual steps of the taught operator- } \\
\text { specific action are implemented in the } \\
\text { course of the response. } \\
\text { Iva1.1.3.2: The taught arrangement of the individual } \\
\text { steps of the operator-specific action is } \\
\text { observed. }\end{array}$ \\
\hline \multirow[t]{3}{*}{$\begin{array}{l}\text { Iva1.2: } \\
\text { Result of applying an } \\
\text { operator-specific } \\
\text { consistent, coherent } \\
\text { mental representation } \\
\text { to a task }\end{array}$} & $\begin{array}{l}\text { Iva1.2.1: } \\
\text { Result of the application of } \\
\text { an operator-specific schema } \\
\text { of conception to a task }\end{array}$ & $\begin{array}{l}\text { Iva1.2.1.1: The processing result of the task shows the } \\
\text { taught conceptually invariant elements of } \\
\text { the operator. } \\
\text { Iva1.2.1.2: The processing result of the task shows the } \\
\text { taught operator-specific perspective. }\end{array}$ \\
\hline & $\begin{array}{l}\text { Iva1.2.2: } \\
\text { Result of applying an } \\
\text { operator-specific schema of } \\
\text { operation to a task }\end{array}$ & $\begin{array}{l}\text { IVA1.2.2.1: The overall structural design of the } \\
\text { processing result of the task corresponds to } \\
\text { the taught action structure of the operator. } \\
\text { Iva1.2.2.2: The processing result of the task shows the } \\
\text { taught connections of the individual sub- } \\
\text { steps of the operator-specific action. }\end{array}$ \\
\hline & $\begin{array}{l}\text { Iva1.2.3: } \\
\text { Result of applying an } \\
\text { operator-specific schema of } \\
\text { action to a task }\end{array}$ & $\begin{array}{l}\text { IVA1.2.3.1: The taught objectives of the sub-steps of the } \\
\text { operator-specific action are present in the } \\
\text { processing result of the task achieved. } \\
\text { IVA1.2.3.2: The taught operator-specific action goal is } \\
\text { present in the processing result of the task } \\
\text { achieved. }\end{array}$ \\
\hline
\end{tabular}

In order to be able to make scientifically justified statements after the quasi-experiment, the data collected are evaluated by means of descriptive statistics and, depending on the data level and the sample size, by means of inferential statistical procedures comparing the two points in time $\left(t_{0}\right.$ und $\left.t_{1}\right)$ at which the quasi-experiment was conducted (Wilcoxon-Test; McNemar-Test) and between the control and test group $\left(\mathrm{G}_{\mathrm{C}}\right.$ and $\mathrm{G}_{\mathrm{T}}$ ) (MannWhitney-U-Test; Chi-square Four-Field-Test with Continuity Correction; Exact Fisher Test) (cf. Author, 2017, p. 212 et sq.). With an error probability of $\alpha<5 \%$ a test result is classified as significant (*) and with $\alpha<1 \%$ as high significant $(* *)$.

\section{Results}

The findings of the experiment show statistically significant differences between $G_{C}$ and $G_{T}$ in the measurement of the first point of time of the survey $\left(t_{0}\right)$ for only a few items (see Table 3 and Table 4 ). 
Table 3: p-values (Mann-Whithney-U-Test; Wilcoxon Test) of the intervention study.

Variable

IVA1.1.1.1

The course of processing depicts operator-specific perspectives of the taught teaching-learning content
$\mathrm{G}_{\mathrm{C}}-\mathrm{G}_{\mathrm{T}}\left(\mathrm{t}_{0}\right) \quad \mathrm{G}_{\mathrm{C}}-\mathrm{G}_{\mathrm{T}}\left(\mathrm{t}_{1}\right) \quad \mathrm{G}_{\mathrm{C}}\left(\mathrm{t}_{0}-\mathrm{t}_{1}\right)$ $p$ (Mann-Whitney-U-Test) $p$ (Wilcoxon-Test)
$.000 * *$

$.004 * *$

$.000 * *$

$.004 * *$
$\mathrm{G}_{\mathrm{T}}\left(\mathrm{t}_{0}-\mathrm{t}_{1}\right)$

\section{IvA1.1.2.1}

Structural development of the taught operator-specific action recognisable in $.013 *$

$.000 * *$ the answer structure

\section{IVA1.1.2.2}

\section{(Correct connection of operator steps)}

Analysis criteria and assignment of the dissected content

Structured learning situation characteristics and orderly examination

$.000 * *$

.316

$.000 * *$

Orderly investigation and derivation of conclusions

Derivation of conclusions and formulation of investigation result

.540

$.000 *$

.692

$.000 * *$

\section{IVA1.1.3.2}

Compliance with the individual steps of

$.013^{*}$

$.000 * *$

$.002 * *$

$.000 * *$

the operator-specific action

\section{IVA1.2.1.2}

Processing result shows taught operator-

$.043 *$

$.001 * *$

$.001 * *$

$.000 * *$ specific perspective

\section{IvA1.2.2.1}

The overall structure of the processing result corresponds to the taught structure .768

$.000 * *$

.289

$.000 * *$ of action

\section{IVA1.2.2.2}

Processing result shows taught connections of the individual steps of the 1.000 $.000 * *$ .297 $.000 * *$ action

\section{IVA1.2.3.2}

Taught operator-specific action goal was $\quad .752$ achieved

$\begin{array}{lll}.000 * * & .688 & .001 * *\end{array}$


Table 4: p-values (Ch²-Test; Fisher Test; Mc-Nemar-Test) of the intervention study.

\begin{tabular}{|c|c|c|c|c|c|c|}
\hline \multirow[b]{2}{*}{ Variable } & \multicolumn{2}{|c|}{$\mathrm{G}_{\mathrm{K}}-\mathrm{G}_{\mathrm{V}}\left(\mathrm{t}_{0}\right)$} & \multicolumn{2}{|c|}{$\mathrm{G}_{\mathrm{K}}-\mathrm{G}_{\mathrm{V}}\left(\mathrm{t}_{1}\right)$} & \multirow{2}{*}{$\begin{array}{l}\mathrm{G}_{\mathrm{K}}\left(\mathrm{t}_{0}-\mathrm{t}_{1}\right) \\
p \\
\text { Mc-Nemar- } \\
\text { Test }\end{array}$} & \multirow{2}{*}{$\begin{array}{l}\mathrm{G}_{\mathrm{V}}\left(\mathrm{t}_{0}-\mathrm{t}_{1}\right) \\
p \\
\text { Mc-Nemar- } \\
\text { Test }\end{array}$} \\
\hline & $\begin{array}{l}p \\
\text { Chi }^{2}- \\
\text { Test }\end{array}$ & $\begin{array}{l}p \\
\text { FisherT } \\
\text { est }\end{array}$ & $\begin{array}{l}p \\
\text { Chi }^{2}- \\
\text { Test }\end{array}$ & $\begin{array}{l}p \\
\text { Fisher } \\
\text { Test }\end{array}$ & & \\
\hline \multicolumn{7}{|c|}{$\begin{array}{l}\text { Iva1.1.3.1 } \\
\text { (Implementation of the operator } \\
\text { steps) }\end{array}$} \\
\hline Short summary & .354 & & & .537 & $.003 * *$ & $.020 *$ \\
\hline Analysis criteria & .381 & & $.019 *$ & & .125 & $.002 * *$ \\
\hline Content dissection & & $.041 *$ & & .152 & .125 & .109 \\
\hline Investigation & 1.000 & & $.00 * *$ & & 1.000 & $.003 * *$ \\
\hline Conclusions & & .221 & $.011 *$ & & $.008 * *$ & $.000 * *$ \\
\hline Analysis result & $\begin{array}{l}\text { const. } \\
\text { value }\end{array}$ & & .066 & & $.016^{*}$ & $0.008 * *$ \\
\hline
\end{tabular}

IVA1.2.1.1

(Processing result contains

invariant elements of the operator)

\begin{tabular}{|c|c|c|c|c|}
\hline Guided by criteria & .818 & $.019 *$ & .453 & $.002 * *$ \\
\hline Dissection of object & $.041 *$ & .152 & .125 & .109 \\
\hline Orderly investigation & 1.000 & $.00 * *$ & 1.000 & $.002 * *$ \\
\hline Valuation free evaluation & .476 & $.010 *$ & .500 & $.002 *$ \\
\hline
\end{tabular}

\begin{tabular}{|c|c|c|c|c|c|c|}
\hline \multicolumn{7}{|c|}{$\begin{array}{l}\text { IVA1.2.3.1 } \\
\text { (Taught objectives of the sub-steps } \\
\text { of the action were achieved) }\end{array}$} \\
\hline Short summary & .354 & & & .537 & $.003 * *$ & $.020^{*}$ \\
\hline Analysis criteria & .381 & & $.019 *$ & & .125 & $.002 * *$ \\
\hline Content dissection & & $.041 *$ & & .426 & .125 & .313 \\
\hline Investigation & & .714 & $.00 * *$ & & 1.000 & $.002 * *$ \\
\hline Conclusions & & .221 & $.013^{*}$ & & $.016^{*}$ & $.000 * *$ \\
\hline Analysis result & $\begin{array}{l}\text { const. } \\
\text { value }\end{array}$ & & & $\begin{array}{l}.006 \\
* *\end{array}$ & .125 & .063 \\
\hline
\end{tabular}

There are significant differences in the items for the course of action of the application of an operator-specific operation schema when processing a task (Item IVA1.1.2.1 and Item IVA1.1.2.2). For the course of action of the application of an operator-specific schema of action when processing a task, the data evaluation of the test at $\mathrm{t}_{0}$ for one item shows a statistically significant difference (Item IVA1.13.1). The findings also show a statistically significant difference for the result of the application of an operator-specific schema of conception to a task in one case (Item $\mathrm{I}_{\mathrm{VA1} \text {.2.1.1 }}$ ). This also applies to one item for the result of the application of an operator-specific scheme of action (Item IVA1.2.3.1). Furthermore, no statistical significance is shown in the findings of the first measurement point. Despite the statistically significant differences identified, the descriptive statistical data evaluation for the items mentioned here shows a concentration of information in the negative response range for both the $\mathrm{G}_{\mathrm{C}}$ and the $\mathrm{G}_{\text {T. }}$. In contrast, the calculations for measuring the second point in time $\left(\mathrm{t}_{1}\right)$ between $\mathrm{G}_{\mathrm{C}}$ and $\mathrm{G}_{\mathrm{T}}$ show, as expected, statistically significant differences for a large number of items (see Table 3 and Table 4). The findings of the descriptive statistics show a more positive expression in the $\mathrm{G}_{\mathrm{T}}$ for all these items. These results support the hypothesis $H_{l}$. The only exceptions are the Items IVA1.13.1, Item IVA1.2.1.1 and Item IVA1.2.3.1.

Contrary to expectations, positive statistically significant changes were found for some items between the two survey dates $\left(t_{0}-t_{1}\right)$ for the control group $\left(G_{C}\right)$ (see Table 3 and Table 4 ). The descriptive statistical data evaluation shows a shift of the information for these items into the positive answer range at $t_{1}$ compared to $t_{0}$. This applies to items of the application of an operator-specific schema of operation to the task in the course of processing (Item $\mathrm{I}_{\mathrm{VA1} 1.12 .1}$, Item $\mathrm{I}_{\mathrm{VA1} 1.12 .2}$ ), items of the application of an operator-specific schema of action to the

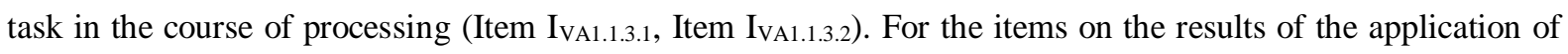
an operator-specific conceptual schema, the tested data for one item also show a statistically significant 
difference between the two survey points (Item IVA1.2.1.2). With regard to the results of the application of an operator-specific schema of action, the findings show statistically significant differences for the Item IVA1.2.3.1. For the remaining items, the calculations show no statistically significant changes for the control group between the two survey points, as expected.

For the test group $\left(\mathrm{G}_{\mathrm{T}}\right)$, the findings of the tests between the two survey points $\left(\mathrm{t}_{0}-\mathrm{t}_{1}\right)$ show positive statistically significant changes, in line with expectations, for all items of the application procedure when processing the task of an operator-specific schema of conception, schema of action and schema of operation (see Table 3 and Table 4). This also applies to the items of the application result when processing the task for the operator-specific schema of conception, schema of action and schema of operation. The findings of the descriptive statistical data evaluation show a shift of the information for these items into the positive response range at $t_{1}$ compared to $t_{0}$. These results support the hypothesis $H_{l}$.

\section{Discussion}

In summary, the experimental results show that the teaching of the meaning and the handling of operators of written tasks has a positive effect on the processing of a written task by the learners. With regard to the development of a mutual understanding of tasks, positive changes can be recognised by the teaching of the meaning and the handling of operators of written tasks. The empirical findings presented here show in part that the teaching of the meaning and the handling of operators of written tasks leads to a hierarchical arrangement of the knowledge structures of the learners with regard to the action required of the teacher in the task. This is especially the case with regard to the course of action of the application of an operator-specific schema of conception as well as the application result of an operator-specific schema of operation. This is confirmed by the inferential statistical data evaluation.

This cannot be proven to this extent for the other operator-specific schemata of the course of action and the application result in the processing of the written tasks. Thus, on the basis of the available results of the study, the development of one mutual understanding of tasks among teachers and learners cannot be established. However, the scope of hypothesis $H_{l}$ is not subject to any general limitation based on the findings of this study. An effect of the treatment is also obvious. Nevertheless, hypothesis $H_{l}$ must be rejected, especially for logical reasons. This is due in particular to the fact that statistically significant differences in the data of both groups can already be identified at the first time of the survey. The inclusion of these items for hypothesis testing is therefore not appropriate, since an effect of the intervention cannot be determined on this data basis.

Thus, the derivation of theory-conforming statements according to Aebli $(1980 ; 1981)$ for all parts of understanding is not possible on the basis of the present investigation results. A randomisation of the sample used for the quasi-experiment was not possible within this study, so that existing natural groups or school classes were involved. The recourse to existing social aggregates for quasi-experimental investigations is usually used (cf. Lamnek, 1989, p. 5; Kromrey, 2009, p. 504). It should be pointed out at this point that failure to randomise the sample is only one possible cause of the statistical differences that arise for $G_{C}-G_{T}$ at $t_{0}$ and that the test results may also show such differences when working with a randomised sample.

Furthermore, it should be noted that individual interpretative components in the understanding of the tasks to be worked on by the individual test persons cannot be excluded, although these components of understanding have already been limited by the design of the quasi-experiment carried out and are not the focus of the investigation due to the theoretical foundation of the present empirical study. Despite the high degree of generalisation of the schema theory focused here (cf. Pastohr, 2008, p. 62), these proportions of understanding tasks must be named as a possible cause of the differences in the results of the work, and it must also be noted that it is not possible to control them completely. 
Another important point of discussion is the need to carry out replication studies of the experimental investigation presented here. The scientific benefit of such studies, especially with larger samples, is seen in the extraction of generalisable statements with a greater range or possibly also for individual occupations, occupational groups or fields of work.

\section{Conclusions}

The following conclusions can be derived from the study for teaching practice and for the development of a mutual understanding of tasks among teachers and learners (cf. Author, 2017, p. 328 et sq.):

Didactic orders, e.g. as written tasks, are the central component of examinations, which serve to realise the intention of the "Control and Assessment" section and aim at knowledge about achieved learning success for the teacher and the learners. In order to successfully complete their training, learners in vocational education and training must be able to deal with didactic orders in examinations in vocational lessons. Due to the purpose of vocational education and training, the didactic orders used in vocational education and training often aim at the execution of occupation-specific actions. Therefore, in vocational lessons, learners should be enabled to carry out these actions by first acquiring, consolidating, deepening and consolidating the relevant content. This too is part of the practical-pedagogical field of activity of a teacher at vocational schools.

Following Segeth's argumentation (1974), a central component of tasks is the operator, with which the request to perform a certain performance-providing action is made. When choosing the operator, it is important to ensure that the expected action is clearly defined and ambiguities are avoided. In addition, it must be ensured that the required action can be carried out by the learners and that the objective of the task can be achieved under the given conditions.

From a didactic point of view, the development of a mutual understanding of tasks among teachers and learners is important for the development of occupation-specific knowledge structures, personality traits that are oriented towards professional actions and professional action competence among learners. The teacher's understanding of tasks forms the basis for the formulation of written tasks in a goal-oriented manner. For a mutual understanding of tasks among teachers and learners, not only the knowledge of the operator's meaning is necessary for the learners, but also the knowledge of the actions required with the operator. The provision of the defined operator meaning and the associated operator-specific action in vocational lessons was necessary for the development of operator-specific schemata and thus for the change of knowledge structures among the learners in the sample of the examined vocational training course "state-approved educator". Similar effects can also be assumed here for larger samples and learners in other occupations, although this will have to be investigated in further research.

Against the background of the research findings, special attention should be paid to developing a mutual understanding of tasks among teachers and learners, and to the importance of and how operators are handled in order to acquire operator-specific schemata in vocational training. However, further methodological and didactic preparatory work will have to be carried out in future studies in order to gain more comprehensive insights into the understanding of didactic requirements in vocational training.

\section{References}

Aebli, H. (1980). Denken: das Ordnen des Tuns. Vol. 1: Kognitive Aspekte der Handlungstheorie. Stuttgart: Klett-Cotta.

Aebli, H. (1981). Denken: das Ordnen des Tuns. Vol. 2: Denkprozesse. Stuttgart: Klett-Cotta.

Aebli, H. (1990). Zwölf Grundformen des Lehrens. 5. Ed. Stuttgart: Klett-Cotta.

Anderson, J. R. (1989). Kognitive Psychologie. Heidelberg: Spektrum der Wissenschaft. 
Author (2017). [Information removed for review process]

Bereiter, C. and Scardamalia, M. (1987). The psychology of written composition. Hillsdale/NJ: Lawrence Erlbaum Associates.

Blackburn, S. (Ed.) (1996). The Oxford Dictionary of Philosophy. Oxford: Oxford University Press.

Chomsky, N. (1957). Syntactic Structures. Den Haag: Mouton.

Conrad, E. and Zenker, K. (1977). Die Bedeutung der Kommunikationsverfahren ,Begründen“ und ,Schlussfolgern` bei der Arbeit im Literaturunterricht. Zwickau: internal script.

Fromme, J. (1997). Pädagogik als Sprachspiel - Zur Pluralisierung der Wissensformen im Zeichen der Postmoderne. Berlin: Luchterhand.

Habermas, J. (1981). Theorie des kommunikativen Handelns. Vol. 1 and 2. Frankfurt/M.: Suhrkamp.

Halder, A. (2003). Philosophisches Wörterbuch. 2. Ed. Freiburg i. Breisgau: Herder.

Harnisch, H. (1983). Zum Wesen von Kommunikationsverfahren. Potsdamer Forschungen der Pädagogischen Hochschule „Karl Liebknecht“; A (57), 41-54.

Hayes, J. (1996). A new framework for understanding cognition and affect in writing. In C. M. Levy and S. Ransdell (Eds.). The science of writing. Mahwah/NJ: Routledge, 1-27.

Hortsch, H. (2005). Didaktik der Berufsbildung. Merkblätter. Dresden: SFPS.

Klauer, K. J. (2005). Das Experiment in der pädagogisch-psychologischen Forschung. Eine Einführung. In H. D. Rost (Ed.). Standardwerke aus Psychologie und Pädagogik, Reprints. Vol. 2. Münster: Waxmann.

Kostrzewa, F. (2009). 'TeacherTalk' - die Unterrichtssprache der Lehrenden. Effektive und weniger effektive Methoden im Vergleich. Deutsch als Zweitsprache, 2009 (4), 29-33.

Kromrey, H. (2009). Empirische Sozialforschung. Modelle und Methoden der standardisierten Datenerhebung und Datenauswertung. Stuttgart: Lucius and Lucius.

Lakoff, G. (1987). Women, Fire, and Dangerous Things: What Categories Reveal About the Mind. Chicago: University of Chicago Press.

Lamnek, S. (1989). Qualitative Sozialforschung - Vol. 2: Methoden und Techniken. München: PsychologieVerlags-Union.

Leont'ev, A. A. (1971). Sprache - Sprechen - Sprechtätigkeit. Stuttgart: Kohlhammer.

Loch, W. (1970). Sprache. In J. Speck and G. Wehle (Eds.), Handbuch pädagogischer Grundbegriffe. Vol. 2. München: Kösel, 481-528.

Lüders, M. (2003). Unterricht als Sprachspiel - Eine systematische und empirische Studie zum Unterrichtsbegriff und zur Unterrichtssprache. Bad Heilbrunn: Klinkhardt.

Lüders, M. (2004). Unterrichtssprache. In W. Helsper and J. Böhme (Eds.): Handbuch der Schulforschung. Wiesbaden: VS Verlag für Sozialwissenschaften.

Luhmann, N. (1984). Soziale Systeme. Grundriß einer allgemeinen Theorie. Frankfurt/M.: Suhrkamp.

Lurija, A. R. (1982). Sprache und Bewußtsein. Berlin: Volk und Wissen.

Mandl, H., Friedrich, H. F. and Hron, A. (1988). Theoretische Ansätze zum Wissenserwerb. In H. Mandl and H. Spada (Eds.), Wissenspsychologie. München: Psychologie-Verlags-Union, 123-160.

Mittelstraß, J. (Ed.). Enzyklopädie Philosophie und Wissenschaftstheorie. Vol. 1. Stuttgart: Metzler.

Montag, H. (1975). Zur kommunikativ-didaktischen Funktion schriftsprachlich formulierter Aufgaben. Dresden: TU Dresden.

Parsons, T. (1937). The Structure of Social Action. New York: Free Press.

Pastohr, M. (2008). Die Leistungsfähigkeit von Systemen tertiärer Bildung an der Schwelle zum Beschäftigungssystem. Dresden: TU Dresden.

Piaget, J. (1969). Das Erwachen der Intelligenz beim Kinde. Stuttgart: Klett.

Pfeifer, W. (Ed.) (1989). Etymologisches Wörterbuch des Deutschen. Berlin: Akademie-Verlag.

Popper, K. (1935). Logik der Forschung. Wien: Julius Springer. 
Priesemann, G. (1971). Zur Theorie der Unterrichtssprache. Düsseldorf: Schwann.

Rorty, R. M. (1967). The linguistic turn: Recent Essays in Philosophical Method. Chicago: The University of Chicago Press.

Schmidt, W. (Ed.) (1981). Funktional-kommunikative Sprachbeschreibung. Theoretisch-methodische Grundlegung. Leipzig: Bibliographisches Institut.

Schnotz, W. (1994). Aufbau von Wissensstrukturen: Untersuchungen zur Kohärenzbildung beim Wissenserwerb mit Texten. Weinheim: Beltz.

Searle, J. (1971). Sprechakte: Ein sprachphilosophischer Essay. Frankfurt/M.: Suhrkamp.

Segeth, W. (1974). Aufforderung als Denkform. Berlin: Akademie-Verlag.

Sonntag, K. (1993). Die Repräsentation beruflicher Wissensstrukturen - Leitgedanken zur Beschaffenheit und Organisation von Wissensstrukturen und ihrer Bedeutung beim Lernen. In H. Hortsch (Ed.). Dresdner Beiträge zur Berufspädagogik. Vol. 3. Dresden: SFPS, 37-51.

Spanhel, D. (1973). Schülersprache und Lernprozesse. Düsseldorf: Schwann.

Wygotski, L. S. (1977). Denken und Sprechen. Frankfurt/M.: Fischer. 